\title{
Use of smartphones in family relationships of university students of the Nacional del Altiplano University of Puno
}

\author{
Uso de los smartphone en las relaciones familiares en estudiantes \\ universitarios de la Universidad Nacional del Altiplano de Puno
}

\author{
Yolanda Pari Ccama \\ https://orcid.org/0000-0002-3551-762X
}

Universidad Nacional del Altiplano, Puno, Peru. yolipari@hotmail.com
Recibido e1: 06/04/2019
Aceptado e1: 20/11/2019

\section{RESUMEN}

El uso excesivo de los Smartphone en los jóvenes ha generado el deterioro en las relaciones familiares. El objetivo de la investigación fue determinar la relación del uso de los Smartphone con las relaciones familiares en estudiantes universitarios. Se aplicó el método hipotético deductivo, la investigación es de tipo descriptivo correlacional, se trabajó con una muestra no probabilística por conveniencia de 96 estudiantes, se aplicó la técnica de la encuesta y como instrumento el cuestionario tipo Likert con 36 ítems planteado por variables, dimensiones e indicadores. Los resultados mostraron que existe una relación entre el uso de los Smartphone con las relaciones familiares, evidenciando el deterioro de la interacción cara a cara entre padres e hijos, poco cumplimiento de las funciones familiares de socialización, de recreación y de afecto que carecen los jóvenes y los estilos de comunicación que practican en casa en su mayoría son pasivas. Llegamos a la conclusión, que el uso de los Smartphone tiene una relación significativa positiva media con las relaciones familiares en estudiantes universitarios. Las instancias educativas y la familia deben regular el uso adecuado de los Smartphone en espacios familiares, evitando el deterioro de las relaciones familiares.

Palabras clave: relaciones familiares, smartphone. 


\section{INTRODUCTION}

Information and communication technologies (ICT) group elements and techniques for the transmission of information, mainly information technology, Internet and telecommunications. Technological changes have brought the Smartphone, becoming a great technological revolution, it is a device that is used as a telephone and that has a considerable computing capacity, allows the integration of applications oriented to different tasks.

The frequent use of smartphones generates changes in the behavior of human beings, the way of communicating, working and living, we no longer respect family spaces to interact or to communicate face to face with our parents.

The smartphone has become an essential tool of the day to day, the user is unable to control, interrupt or stop its use, constantly checking the screen to see if a new message has arrived, a call "lost" or simply to see how time goes by second to second. They have it in their hands or in their shirt pocket or pants, near their body to have a feeling of constant contact with their phone (Ticona \& Tupac, 2016). The smartphone can generate mood changes, anxiety, insecurity, fear of leaving without a cell phone. A certain psychological dependence can also be observed: the inability to control or interrupt its use (Masías, 2014). This addiction has changed the way we 52 work, socialize and live our lives, impacting and generating dependence that is called Nomophobia, a disease caused by the irrational fear of not taking the phone with us since going outside without a mobile can create instability, aggressiveness and difficulties in concentration (Cascón, Gutierrez, Lopéz, \& Santiago, 2011).

We live in a world where communication between people is vital and technologies facilitate this communication, even if it is not physically. This phenomenon generates greater dependence on adolescents, there is a great use of mobile technologies, it is indirectly favored by the parents themselves, who feel more secure in being able to communicate with their children. But this addiction has changed the way people work and how people socialize (Cascón, Gutierrez, Lopéz, \& Santiago, 2011).
The new mobile technology has given way to virtual socialization spaces and has displaced the face-to-face ones. This has generated behavioral changes in individuals, especially in young people who have been born and have developed in the sphere of change (Peñuela, M., Paternina, J., Moreno, D., Camacho, L., Acosta, Barrios., \& De León, 2014).

The smartphone is considered an educational distractor; it offers applications that can support any educational modality. Moreover, it offers alternatives for use in student mobility conditions. Because of the potential wealth it provides as a pedagogical tool, it is conceived as an activity directly related to the management of available information and communication. The success of this process is achieved when individuals are able to solve contextualized problems in their real life, to communicate the information and found knowledge. (Sandoval, Salas \& Gilles, 2013).

ICT, has opened the way to better understanding the important social processes that occur in youth, cultural processes, patterns of thought, knowledge and behavior that are occurring in family relationships and that flatly affect the way young people meet know, prosecute and use ICT (Lorente, Bernete \& Becerril, 2004).

The students of the Professional School of Social Work are not oblivious to this problem that presents the current context, the use of smartphones has become an opportunity and a threat for young university students, allows them to access to obtain information and communicate with their relatives, but after that generates negative aspects and changes in behavior, ways of communicating, working, living together and caught by the frequent use of smartphones, spending more time, it is not uncommon to see young people answer calls , play with the cell phone, answer messages, and some even stay connected to the Internet throughout the day, causing interruption, diverting attention to the family space and deterioration family relationships.

The objective of the research is to determine the relationship of the use of Smartphone with family relationships in university students of the Faculty of Social Work of the Nacional del Altiplano University of Puno 2017. The theoretical support framework is developed, then the methodology and finally the results and discussion. 


\section{THEORETICAL FRAMEWORK}

\section{Theoretical and Psychological Bases of Smartphone Use}

Among the main psychological theories related to the use of the Smartphone, the following were developed: theory of uses and gratifications, theory of self-determination, cognitive social theory and the theory of dependence on the environment. The use of these theoretical bases, gives us the possibility to understand from a scientific perspective the use of the Smartphone.

The Theory of use and gratifications, indicates that individuals use the media to achieve various objectives and purposes. Exposure to the media is determined by your specific intentions composed of personal and social motivations. The Smartphone offers the possibility of multiple uses and perks for individuals such as "utilitarians": device functionalities and "hedonic": related to leisure and interpersonal relationships (Gaspar, 2015).

People employ the following categories: communication, voice calls, messages, instant messaging (WhatsApp type), making or receiving calls is the most basic function of mobile phones, social networks. Smartphones have facilitated these functions. Thanks to applications (mobile applications), there are more possibilities such as sending photos or videos. Young users mostly use the smartphone with entertainment fines, express their personal identity and build interpersonal relationships.

The theory of self-determination is based on the satisfaction of three basic psychological needs: competence, autonomy and the ability to relate. Analyze the degree to which human behaviors are volitional or self-determined. It establishes the degree to which people execute the actions at the highest level of reflection and with a sense of choice based on their own will (Gaspar, 2016).

The theory of dependence on fear, analyzes the dependence of users in their relations with the ubiquity of media systems. The media are considered as an important system and part of the social fabric of modern society. Therefore, they can have relationships with individuals, groups, organizations and other social systems. All of them achieve their personal and collective goals by relying on the resources of others and vice versa.
The individual seeks to achieve his own goals and for this they need information resources controlled by the mass media. Therefore, entertainment is understood as the ability of the media to provide mechanisms to relax and relieve stress when individuals are alone or accompanied by others (Gaspar, 2016).

Smartphones are capable of sending text messages, accessing the Internet, social networks, music, videos, chats, emails and all kinds of applications that the user wishes to download (Peñuela et al., 2014) is a device that contains various Utilities such as a camera, 4G technology, Wi-Fi and other components that make it a mobile device of the latest technology.

The new mobile technology has given way to virtual socialization spaces and has displaced face-to-face ones. This has generated behavioral changes in individuals, especially in young people who have been born and have developed in the sphere of change (Peñuela et al., 2014).

The use of the smartphone affects the identity of the users in four aspects: personal image, autonomy, construction of the I and collective identity. It is also a means of symbolic communication since it says things about its owner to the extent that it has been incorporated as part of its public image, helping to characterize said person. Being connected to the group and being identified as part of it is especially relevant at this stage of life, in which the young person moves away from family referents and it is friends who acquire greater weight as a source of experiences and meanings from of which the identity is elaborated. The cell phone becomes an important part of teenagers' lives, becoming a source of expression of their identity and independence (Yarto, 2009).

Young people use their Smartphone anywhere and anytime, it produces an enveloping use characterized by the encapsulation of cognitive and behavioral aspects of this device. Users who make this type of use have two distinct components, a cognitive component, thoughts and desires towards the Smartphone. The subjects have anxiety, depression and social loneliness if they do not have the phone nearby. On the other hand, a behavioral component that consists of continuous checking and closeness of the Smartphone, young people who make a smartphone use are anxious but receive calls or 
notifications and worried if there are no updates or new news (Gaspar, 2016).

Parents are an important part in the relationship of children with the Smartphone, in many cases they can manage the time of use of the Smartphone, by young people. They observe that sometimes their children spend too much time with the Smartphone and that it can become a tool with some danger (Gaspar, 2016). In work and social environments after the emergence of new technologies and exaggerated use has caused problems for people (Gamero et al., 2016).

\section{General systems theory}

The family is an organized and interdependent set of people in constant interaction, it is a totality, beyond the members that make up the family. This totality is constructed through a system of shared values and beliefs, by the experiences lived throughout life, it gives an identity to the group, strengthening the sense of belonging of its members, building their own personal identity in the middle (Spinal, 2006). It is understood as an interactive communication system, which can present difficulties in everyday life that is established among its members (Rodríguez, 2016).

The family relationship is understood as the transactional symbolic process of generating, within the family system, meanings to events, things and situations of the daily life; It is a process 34 of mutual and evolutionary influence that includes verbal and nonverbal messages, perceptions, feelings and cognitions of family group members. The relationship occurs in a cultural, environmental and historical context and results in creating and sharing meanings (Gallegos, 2006).

Today, family communication has become complex, since interaction takes place more electronically, where regulations or rules do not work or simply do not exist and communication patterns have become repetitive, discriminating the form of direct communication that had been implemented. for centuries within families (Calderón et al., 2016).

\section{METHODOLOGY}

The study was conducted in the Professional School of Social Work of the Nacional del Altiplano University of Puno. The research includes quantitative approach deductive hypothetical method (Hernández, Fernández \& Baptista, 2010) the research design is nonexperimental, because it was not manipulated, nor tested the variables under study; It is transversal, because it is responsible for collecting the data in a single moment; It is correlational, because it seeks to know the relationship of the study variables, the use of the Smartphone with family relationships in university students.

We worked with the type of non-probabilistic sample for convenience. A sample is not probabilistic when the probability of inclusion in the sample is not known for all the selected elements, or when part of the universe had no probability of inclusion (Valencia, 1972), not all members of the population have the same opportunity if included in the sample (McMillan \& Schumacher, 2001). The researcher uses subjects that are accessible or represent certain characteristics (Creswell, 2008), defines it as a quantitative sampling procedure in which the researcher selects the participants, since they are willing and available to be studied.

The size of the study population was determined under the non-probabilistic sample for convenience that was 96 students representing $15 \%$ of the total population of 640 , the criteria considered by the researcher were age, sex, place of origin and the cycle level, these criteria allowed to collect the true information in the population and for this purpose the survey technique and the Likert type questionnaire instrument were applied, which included 36 items according to the variables; Use of Smartphone and family relationships, dimensions raised by each specific objective; instrumental dimension of Smartphone use and changes in family structure, symbolic dimension of Smartphone use and family functions, daily use of Smartphone and communication.

For the data processing the statistical program SPS 22 was used and the type of analysis was the Pearson correlational descriptive that allowed us to know the estimation and contrast of hypotheses according to the sample size.

\section{RESULTS AND DISCUSSION}
The relationship of the instrumental dimension of smartphone use with changes in family structure in university students


In Table 1, of the communicative function of the use of the Smartphone, $49 \%$ of the survey respondents representing 47 students state that they often use the Smartphone to communicate with their family and friends and join the social networks of Twitter, Facebook and WhatsApp. While $27 \%$ representing 26 students stated that sometimes they use the Smartphone to be located with parents, this generates little space for dialogue and family behavior in families, young people give higher priority to social networks and every time family face-to-face relationships between parents and children are deteriorating.

Table 2 of nuclear, single-parent and extended families shows 51\% representing 49 surveyed students said that family relationships between parents and children often deteriorate. While 50\% representing 48 students report that sometimes nuclear, single-parent, large families have little space for dialogue and family behavior. Given these results, we can deduce that families have suffered a change in family structure, as a result of the use of ICT, where families have lost family physical spaces of sharing, socialization, recreation between parents and children face to face.

Peñuela et al. (2014) indicated that the new mobile technology has given way to virtual socialization spaces and displaced face-to-face relationships in families. The results obtained corroborate this phenomenon within the families of the social work students of UNAP. Where family relationships deteriorate. Calderón et al. (2016), emphasizes that the family relationship has been influenced by technological advancement and the use of social networks, producing great changes that have facilitated communication and personal relationships regardless of place or distance. In this way, today family communication has become complex, since the interaction takes place more by electronic means, where regulations or rules do not work or simply do not exist and communicational patterns have become repetitive discriminating the form of direct communication which had been implemented for centuries within families.

Table 1.

Instrumental dimension: Communicative Function

\begin{tabular}{|c|c|c|c|c|c|c|c|c|}
\hline \multirow{2}{*}{$\begin{array}{l}\text { DIMENSION INSTRUMENTAL: } \\
\text { Communicative Function }\end{array}$} & \multicolumn{5}{|c|}{ Never Rarely Sometimes Often } & \multicolumn{3}{|c|}{ Always Total } \\
\hline & F \% & F $\%$ & $\mathbf{F}$ & $\%$ & F \% & $\mathbf{F}$ & $\%$ & $\mathbf{N}^{\circ}$ \\
\hline $\begin{array}{l}\text { I communicate interactively with my family } \\
\text { and friends I insert in the social networks of } \\
\text { Twitter, Facebook and WhatsApp, also to } \\
\text { inform myself and give protests about } \\
\text { collective actions. }\end{array}$ & 44 & 1415 & 20 & 21 & 4749 & 11 & 11 & 96 \\
\hline $\begin{array}{l}\text { I am located and controlled by parents and I } \\
\text { self-explain. }\end{array}$ & 1213 & 2829 & 26 & 27 & 2223 & 8 & 8 & 96 \\
\hline $\begin{array}{l}\text { I access general taxi services, police, } \\
\text { ambulance, emergency and specific services } \\
\text { of SMS chat, chat contacts. }\end{array}$ & 2627 & 2930 & 29 & 31 & 88 & 4 & 4 & 96 \\
\hline TOTAL & 22.1 & 2829 & 45 & 46.9 & 181 & 83 & 3.1 & 96 \\
\hline
\end{tabular}

Source: Survey applied to university students of the Faculty of Social Work of the Nacional del Altiplano University.

Table 2.

Dimension changes in family structure: Nuclear families, single parent and extended families

\begin{tabular}{|c|c|c|c|c|c|c|c|c|c|}
\hline \multirow{2}{*}{$\begin{array}{l}\text { DIMENSION CHANGES IN THE } \\
\text { FAMILY STRUCTURE: Nuclear, single- } \\
\text { parent, extended families }\end{array}$} & \multicolumn{9}{|c|}{ Never Rarely Sometimes Often Always Total } \\
\hline & $\overline{\mathbf{F}}$ & $\%$ & $\mathbf{F}$ & $\%$ & $\mathbf{F}$ & $\%$ & $\mathrm{~F} \% \mathrm{~F}$ & $\%$ & $\mathbf{N}^{\circ}$ \\
\hline Little space for dialogue and family sharing & 1 & 1 & 9 & 10 & 48 & 50 & 31327 & 7 & 96 \\
\hline Parents dedicated to work and neglect children & 1( & 11 & 19 & 20 & 51 & 53 & $\begin{array}{lll}9 & 9 & 7\end{array}$ & 7 & 96 \\
\hline Children free of control and at risk & 2 & 3 & 2 & 22 & 57 & 59 & $\begin{array}{lll}8 & 8 & 8\end{array}$ & 8 & 96 \\
\hline $\begin{array}{l}\text { Deterioration of family relationships between } \\
\text { parents and children. }\end{array}$ & 3 & 3 & 1 & 12 & 26 & 27 & 49517 & 7 & 96 \\
\hline TOTAL & 0 & 0 & 6 & 6 & 00 & 69 & 18196 & 6 & 96 \\
\hline
\end{tabular}

Source: Survey applied to university students of the Faculty of Social Work of the Nacional del Altiplano University. 
The relation of the symbolic dimension of the use of the Smartphone with the family functions in university students

In table 3 of the symbolic dimension of the referential function, it is shown that $47 \%$ representing 45 students indicated that they sometimes use the Smartphone as a referential function to self-affirm their identity in front of the peer group, interest group or membership. While $38 \%$ representing 36 students indicated that they rarely use the Smartphone as a referential function to motivate themselves and choose as a priority in telephone spending and on the other hand they seek to self-affirm their identity in front of the peer and membership group.

Table 4 of the family functions - Socializing function dimension shows that $50 \%$ representing 48 surveyed students stated that in their family parents and children often do not share spaces of socialization face to face, in the current context families They have limited time to talk with their children.

Yarto (2009) claimed that the use of the cell phone affects the identity of users at the level of aspects such as personal image, autonomy, self- construction and collective identity, becomes an important part of teenagers' lives, becoming in a source of expression of their identity and independence. The results of the research coincide with what the authors said within the social work students of UNAP. Identity is affirmed in front of the peer group and interest group.

The General System Theory highlights that the family is the development system of the person, conceived as the set of interrelations that occur within the environment. For (Isaac, 2001) socialization is a complex process and that the family plays an important role in transmitting to children: norms, values, behavior patterns, skills and abilities to act in society, laying the foundations of the basic personality of the boys and girls The results obtained show this phenomenon within the families of the social work students of UNAP. Where the family is the first social group that knows the child and develops. Nowadays, families dedicate little time to their children and take advantage of those spaces in being entertained with the use of Smartphone, where the family should fulfill the socializing function in transmitting love, affection, educational spaces of coexistence and dedication, function That day by day has deteriorated.

Table 3.

Symbolic dimension of Smartphone use: Referential Function

\begin{tabular}{lllllllllllll}
\hline DIMENSION & \multicolumn{1}{c}{ Never Rarely Sometimes Often Always Total } \\
\cline { 2 - 9 } SYMBOLIC: Referential Function & F & $\%$ & F & $\%$ & F & \% & F & $\%$ & F & $\%$ & N $^{\circ}$ \\
\hline $\begin{array}{l}\text { Motivational in the ability to choose or } \\
\text { prioritize mobile phone spending. }\end{array}$ & 8 & 8 & 36 & 38 & 34 & 35 & 15 & 16 & 3 & 3 & 96 \\
$\begin{array}{l}\text { Identity self- assertion against the peer group, } \\
\text { interest group or social category of belonging. }\end{array}$ & 7 & 7 & 31 & 32 & 45 & 47 & 12 & 13 & 1 & 1 & 96 \\
\hline TOTAL DIMENSION & 0 & 2 & 2 & 59 & 62 & 33 & 34 & 2 & 2 & 96 \\
\hline
\end{tabular}

Source: Survey applied to university students of the Faculty of Social Work of the Nacional del Altiplano University.

Table 4

Family functions dimension: Socializing function

\begin{tabular}{|c|c|c|c|c|c|c|c|c|c|}
\hline \multirow{2}{*}{$\begin{array}{l}\text { DIMENSION FAMILY FUNCTIONS: } \\
\text { Socializing function }\end{array}$} & \multicolumn{9}{|c|}{ Never Rarely Sometimes Often Always Total } \\
\hline & $\mathbf{F}$ & $\%$ & $\mathbf{F}$ & $\%$ & $\mathbf{F}$ & $\%$ & F $\% \mathbf{F}$ & $\%$ & $\mathbf{N}^{\circ}$ \\
\hline $\begin{array}{l}\text { Limited dialogue time dedicated by parents to } \\
\text { children. }\end{array}$ & 6 & 6 & 40 & 42 & 32 & 33 & 13145 & 5 & 96 \\
\hline $\begin{array}{l}\text { Parents and children do not share spaces of } \\
\text { socialization face to face. }\end{array}$ & 6 & 6 & 21 & 22 & 15 & 15 & 48507 & 7 & 96 \\
\hline TOTAL & 0 & 0 & 2 & 2 & 68 & 71 & 24252 & 2 & 96 \\
\hline
\end{tabular}

Source: Survey applied to university students of the Faculty of Social Work of the Nacional del Altiplano University. 
The relationship of the daily use of the Smartphone with the communication in university students of the Faculty of Social Work of the Nacional del Altiplano University. Puno 2017.

In Table 5, the frequency of use shown that $35 \%$ representing 34 students indicated that often dedicate one hour a day to inform me on social networks, most college students use every day often the Smartphone, while 31\% representing 30 students said that the frequency of use of the Smartphone devotes 3 hours to more as a distraction. The frequent use of smartphones, in these times has changed in the behavior of human beings, in the way of communicating, working and living, we no longer respect the spaces of being with the family, interacting, communicating face to face with our parents.

Table 6 of the Smartphone's daily use dimension - place of use, shows that $47 \%$ representing 45 students indicated that they often do it at home to review social networks as part of leisure, as well as the fact of using the Smartphone at home is related to the communication styles that are practiced within the home, such as passive, aggressive and assertive.

Gamero etal.,(2016) stated that, in recentyears there has been an exaggerated use of the Smartphone, causing problems at a personal, work, family, academic and social level, generating dependency, loss of control of the person over their behavior. The results reaffirm this phenomenon within the families of the social work students of UNAP. Where family relationships deteriorate. Gaspar (2016) added young people use their Smartphone anywhere and anytime without respecting family spaces. Students feel delighted, anxious about the cell phone and show anxiety, depression and social loneliness if they don't have the phone nearby. Ratificaba Guzmán (2016) young people exert passive communication within the family, do not express their needs, ideas and opinions.

Table 5.

Dimension Daily use of the Smartphone: Frequency of use

\begin{tabular}{llllllllllll}
\hline DIMENSION EVERYDAY USE: & \multicolumn{7}{c}{ Never Rarely Sometimes Often Always Total } \\
\cline { 2 - 10 } $\begin{array}{l}\text { Frequency of use } \\
\text { F }\end{array}$ & $\%$ & F & $\%$ & F & $\%$ & F & $\%$ & F & $\%$ & $\mathbf{N}^{\circ}$ \\
\hline $\begin{array}{l}\text { I dedicate 30 minutes a day to communicate } \\
\text { with my parents. }\end{array}$ & 14 & 15 & 27 & 28 & 23 & 24 & 24 & 25 & 8 & 8 & 96 \\
$\begin{array}{l}\text { I dedicate } 1 \text { hour a day to inform me on social } \\
\text { networks. }\end{array}$ & 2 & 2 & 20 & 21 & 26 & 27 & 34 & 35 & 14 & 15 & 96 \\
$\begin{array}{l}\text { I dedicate 2 hours a day for leisure on social } \\
\text { networks. }\end{array}$ & 8 & 8 & 29 & 30 & 32 & 33 & 20 & 21 & 7 & 8 & 96 \\
I dedicate 3 hours to more as a distractor. & 13 & 14 & 32 & 33 & 30 & 31 & 14 & 15 & 7 & 7 & 96 \\
\hline TOTAL & 0 & 0 & 21 & 22 & 63 & 66 & 10 & 10 & 2 & 2 & 96 \\
\hline
\end{tabular}

Source: Survey applied to university students of the Faculty of Social Work of the Nacional del Altiplano University.

Table 6.

Dimension Daily use of the Smartphone: Place of use

\begin{tabular}{lllllllllllll}
\hline DIMENSION EVERYDAY USE OF & \multicolumn{9}{c}{ Never Rarely Sometimes Often Always Total } \\
\cline { 2 - 10 } SMARTPHONE: Place of use & $\mathbf{F}$ & $\mathbf{\%}$ & $\mathbf{F}$ & $\mathbf{\%}$ & $\mathbf{F}$ & $\mathbf{\%}$ & $\mathbf{F}$ & $\mathbf{\%}$ & $\mathbf{F}$ & $\mathbf{\%}$ & $\mathbf{N}^{\circ}$ \\
\hline Street. & 14 & 15 & 41 & 42 & 2.3 & 24 & 13 & 14 & 5 & 5 & 96 \\
Means of transport. & 9 & 9 & 27 & 28 & 30 & 31 & 23 & 24 & 7 & 8 & 96 \\
Home. & 2 & 2 & 6 & 6 & 25 & 26 & 45 & 47 & 18 & 19 & 96 \\
Study center. & 6 & 6 & 30 & 31 & 35 & 37 & 21 & 22 & 4 & 4 & 96 \\
House of friends or family & 17 & 18 & 32 & 33 & 32 & 33 & 14 & 15 & 1 & 1 & 96 \\
Everywhere & 8 & 8 & 32 & 33 & 27 & 28 & 20 & 21 & 9 & 10 & 96 \\
\hline TOTAL & 0 & 0 & 21 & 22 & 63 & 66 & 10 & 10 & 2 & 2 & 96 \\
\hline
\end{tabular}

Source: Survey applied to university students of the Faculty of Social Work of the Nacional del Altiplano University. 


\section{CONCLUSIONS}

- There is a significant relationship between the use of the Smartphone and family relationships with a medium level of positive correlation. These data show that the use of Smartphone is related to the lifestyles that young university students, where family relationships are deteriorating between parents and children. There is inadequate fulfillment of family, socialization, recreation and affection functions that young people lack. They are delighted by smartphones and the communication styles they practice in their home is passive.

- There is also a significant positive relationship between the instrumental dimension of the use of the Smartphone and the changes in family structure. Families have suffered a change in family structure, as a result of the use of ICT, families have lost family physical spaces of sharing, socialization, recreation between parents and children face to face.

- It is shown that there is a significant positive relationship between the symbolic dimension of the Smartphone and family functions, the use of the Smartphone affects the construction of the identity of the users and is considered as a means of symbolic communication that has given way to the virtual spaces of socialization, displacing face-to-face relationships, generating behavioral changes in young people.

- There is a significant positive relationship between the daily use of the Smartphone and communication, where young people use their Smartphone at any place and occasion generating dependence, loss of control over their behavior and this is related to a passive communication practice, because Young people are limited to expressing their feelings, emotions, opinions and needs.

\section{BIBLIOGRAPHIC REFERENCES}

Braz, A., \& Cômodo, Camila. Del Prette, Z. (2013). Habilidades sociales e intergeneracionalidad en las relaciones familiares. Apuntes de Psicología, 31(2012), 77-84. Recuperado de https://repositorio-aberto.up.pt/ bitstream/10216/70462/2/91243.pdf
Cala, M., Megret, T. (2013). Funciones básicas de la familia. Reflexiones para la orientación psicológica educativa. Red de Revistas Científicas de América Latina, el Caribe, España y Portugal Vol 13 60-71. Recuperado de $\quad$ http://www.redalyc.org/articulo. oa? id $=475748683007$

Calderón, A., Calderon, M., Gualdron, M., y Rojas, K. (2016). Comunicación Asertiva para Construir Familias Positivas. (Tesis de pregrado) Universidad Nacional Abiertta y a Distancia, Bucaramanga. 1-88.

Cascón, M., Gutierrez, C., Lopéz, j., y Santiago, M. (2011). Smartphones, Necesidad o dependencia. 2.06220.

Cava, J. M. (2003). Comunicación Familiar y Bienestar Psicosocial En Adolescentes. Universidad de Valencia. España. Actas Del VIII Congreso Nacional de Psicología Social, 1(1), 23-27. Recuperado de https://doi. org/10.1017/CBO9781107415324.004

Choliz M, Villanueva V, Choliz M. (2009). Revista española de drogodependencia 34(1), 74-88

Cuesta, U. (2012). Uso envolvente del movil en jovenes: propuesta de un modelo de analisis. Universidad Complutense. Madrid. 18(SPEC. OCTOBER), 253-261. Recuperado de https:// doi.org/10.5209/rev-ESMP.2012.v18.40979

Cuti, Y. (2016). Relaciones familiares y desempeño laboral (Tesis de pregrado). Universidad Nacional del Altiplano, Puno. 221.

Escurra, M. y Salas, E. (2014). Construcción y validación del cuestionario de adicción a redes sociales (ARS). Universidad Nacional Mayor de San Marcos. Perú. 20(1), 73-91. Recuperado de http://www.redalyc.org/ revista.oa?id $=686$

Espinal, I. Gimeno, A. y Gonzales, F. (2006). El enfoque Sistémico en los Estudios sobre la Familia. Universidad Autónoma de Santo Domingo UASD. (1), 1-14. Recuperado de http://www.uv.es/jugar2/EnfoqueSistemico. pdf\%5Cnhttp://www.gaiasconsultores.com/ manuales/2013 11_22_18 50_06.pdf

Gallego, S. (2006). Comunicación Familiar: un Mundo de Construcciones Simbólicas y Relacionales. Manizales, Colombia: Editorial Universidad de Caldas.

Gaspar, S. (2016). Bases psicosociales del uso del Smartphone en jóvenes: un análisis motivacional y Cross-cultural (Tesis doctoral). Universidad Complutense, Madrid. 84-669. 
Hernández, R. (2017). Metodología de la Investigación. In P. Fernández, C., y Baptista (Ed.), The British Journal of Psychiatry (6ta. Edición, Vol. 112). Recuperado de https://doi. org/10.1192/bjp.112.483.211-a

Hernández, J., Herrera, P., y Mena, M. (2018). Entrenamientosocio-psicológicoparamejorar la competencia comunicativa interpersonal: estudio de un caso COMUNI@CCION: Revista de Investigación en Comunicación y Desarrollo, 9(2), 79-89. Disponible en http:// www.comunicacionunap.com/index.php/rev/ artice/view/279/160

López, A. (2015). Influencia de la Estructura Familiar sobre el Nivel del Rendimiento Académico. Universidad Nacional del Callao, Lima. 2015.

Lorente, S., Bernete, F., y Becerril, D. (2004). Jóvenes, relaciones familiares y tecnologías de la información y de la comunicación. Universidad Politécnica, Madrid. (1ra.Edició; S. Sanchez, ed.).

Masias,M.(2014).Adicciónalmóvilysurepercusión en la salud de la población juvenil de Navarra. (Monografía en Internet). Pamplona Universidad Pública de Navarra. [Aprox. 47p.]. Disponible en http://academica-e. unavarra.es/handle/2454/1142521.

Medina, M. (2014). El smartphone en la construcción de la identidad del adolescente (Tesis de pregrado). Pontificia Universidad Católica, Perú. Pontificia Universidad Católica Del Perú. Recuperado de http://tesis.pucp. edu.pe/repositorio/handle/123456789/5085

Mendoza, R., Baena, G., y Baena, M. (2007). Un Análisis de la adicción a los dispositivos móviles y su impacto en el rendimiento académico de los estudiantes de literatura. Universidad Autónoma del Estado, Mexico. Recuperado de http://atlante.eumed.net/wpcontent/uploads/moviles.pdf
Navarra. (2016). Uso de dispositivos móviles (teléfonos móviles,smartphones, ebooks, GPS y tablets). Gobierno de Navarra, 29. Recuperado de http://www.navarra.es/NR/ rdonlyres/48F9746B-080C-4DEA-BD95-A5 B6E01797E1/315641/7Usodedispositivosmo viles.pdf

Oliva, A. (2006). Relaciones Familiares y Desarrollo Adolescente. Universidad, Barcelona. Anuario de Psicología, 37, 209 223.

Peñuela, M., Paternina, J., Moreno, D., Camacho, L., Acosta Barrios, L., De León, L. (2014). El uso de los Smartphone y las relaciones interpersonales de los jóvenes. Universidad de Barranquilla, Colombia. 30(3), 335-346. Recuperado de http://dx.doi.org/10.14482/

Rodríguez, A. (2016). La Comunicación Familiar. Una Lectura desde la Terapia Familiar Sistémica. 6445, 26-43. Recuperado de https://doi.org/10.17151/rlef.2016.8.3

Sandoval, j. Salas, L., y Gilles, L. (2013). El teléfono inteligente (Smartphone) como herramienta pedagógica. Universidad de Guadalajara, México. 05, 6-19.

Ticona, Y., y Tupac, E. (2016). Características del uso y dependencia al móvil en estudiantes de enfermería. (Tesis de pregrado) Universidad Nacional de San Agustín, Arequipa. 1-82.

Torres, Y. y Medina, E. (2017). El entrenamiento socio-psicológico para el desarrollo de la comunicación interpersonal. Revista Electrónica Interactiva Opuntia Brava, 9(4), 145-154. Disponible en http://opuntiabrava. ult.edu.cu/index.php/opuntiabrava/article/ view/217. Accedido en noviembre del 2018

Yarto, C. (2009). El teléfono celular y la construcción de la identidad. Instituto tecnológico y de estudios superiores de Monterrey. 